\title{
Synthetic musks fragrances in the aquatic environment: in vitro toxicological studies of their biotransformation and potential negative effects
}

\author{
S. Focardi, C. Della Torre, M. Monti, T. Biagini \& I. Corsi \\ Department of Environmental Sciences "G. Sarfatti", \\ University of Siena, Italy
}

\begin{abstract}
The aim of the present study was to investigate the interaction of musk xylene (MX) and Tonalide (AHTN) with CYP1A by looking at gene transcription (cypla) and EROD activity in Poeciliopsis lucida hepatoma cell line (PLHC-1). MX and AHTN were studied individually and combined with classical inducer of CYP1A as B(a)P and PCB126. After 24h of exposure a different cytotoxicity has been observed with an $\mathrm{LC}_{50}$ of $35.76 \mu \mathrm{M}$ for AHTN and $\mathrm{LC}_{50} 123.6 \mu \mathrm{M}$ for MX. After $6 \mathrm{~h}$ of exposure to MX, a dose-dependent reduction of cyp 1a was observed respect to controls. At $24 \mathrm{~h}$, the same pattern was observed but with slight induction at the lowest concentration $(2 \mu \mathrm{M})$ and a dose-dependent reduction at the higher concentrations. Co-exposure to $\mathrm{MX}$ with $\mathrm{B}(\mathrm{a}) \mathrm{P}$ did not alter cyp 1a transcription levels compared to the inducer alone. After 6h AHTN determined a slight induction of cypla transcription reaching maximum induction of 2.3 folds respect to controls at $2 \mu \mathrm{M}$. No modulation of cypla transcription was observed after $24 \mathrm{~h}$. Co-exposure to AHTN with $\mathrm{B}(\mathrm{a}) \mathrm{P}$ and PCB126 at $6 \mathrm{~h}$ determined a 55\% reduction of cypla transcription respect to inducers alone which recovered at $24 \mathrm{~h}$. At $24 \mathrm{~h}$, MX caused a dose-dependent decrease of EROD activity. No modulation of EROD activity was detectable at $6 \mathrm{~h}$ and 24h of exposure to AHTN. Co-exposure with both MX and AHTN did not alter EROD activity induced by B(a)P and PCB126. Results suggest different toxicological properties of MX and AHTN toward CYP1A in PLHC-1. MX reduced cyp $1 a$ basal transcription but did not alter cypla induction by $\mathrm{B}(\mathrm{a}) \mathrm{P}$ and PCB126. This suggests that MX cellular pathway is not mediated by AhR. On
\end{abstract}


the contrary AHTN did not alter significantly cypla basal levels but decreased cypla induction by B(a)P and PCB126. A potential role of AHTN as competitive antagonist of AhR could thus be hypothesized.

Keywords: synthetic musks, PLHC-1, CYP1A.

\section{Introduction}

In recent years, emerging organic contaminants known as pharmaceutical and personal-care products (PPCPs) have increasingly been released into the environment. PPCPs include many substances with a broad spectrum of uses, including musk fragrances [1]. They are divided into two categories, nitro- and polycyclic musks and are commonly added to detergents, perfumes, soaps and cosmetics. Nitromusks, as musk xylene (1-tert-butyl-3,5-dimethyl-2,4,6trinitrobenzene, MX) are synthetic di- and tri-nitrobenzene derivatives, while polycyclic musks such as Tonalide (7-acetyl-1,1,3,4,4,6-hexamethyltetrahydroxaphtalene, AHTN) are indane and tetraline derivatives highly substituted by methyl groups.

Considered widespread environmental contaminants, MX and AHTN have been detected in the atmosphere, water, sludge and sediments. Levels in surface waters are in the ng- $\mu \mathrm{g} / \mathrm{L}$ range for both musks [1-5] so that exposure of aquatic biota is mainly related to waste water treatment plants.

The lipophilic nature of both compounds (log Kow MX $=4.90$; log Kow AHTN $=5.70$ ) suggests high bioaccumulation potential for aquatic biota, leading to levels in the $\mu \mathrm{g}-\mathrm{mg} / \mathrm{kg}$ lipid basis range $[4,6]$.

With regards to their toxicity to aquatic species, MX and AHTN inhibits multixenobiotic resistance in mussel (Mytilus californianus) with $\mathrm{IC}_{50}$ of 0.97 $\mu \mathrm{M}$ for $\mathrm{MX}$ and $\mathrm{IC}_{50}$ of $2.05 \mu \mathrm{M}$ for AHTN [7, 8]. MX has been reported to be embryotoxic in zebrafish (Danio rerio) [9] and AHTN induce alteration of hearth rate at $33 \mu \mathrm{M}$ [9]. Some studies describe the potential estrogenic/anti-estrogenic effects of MX and its metabolites as well as AHTN. MX metabolites 2-aminoMX and 4-amino-MX seem to bind oestrogen receptors (ER) competitively in vitro in rainbow trout (Onchorynkus mykiss) and in the South African clawed frog (Xenopus laevis) [10]. In zebrafish, antiestrogenic effects have been reported for AHTN mainly mediated by ER $\gamma$ [11]. An induction of ER $\alpha$ and vitellogenin expression has been reported in males of Oryzias latipes at $500 \mu \mathrm{g} / \mathrm{L}$ of AHTN [12]. Despite acute and chronic effects have been observed at doses exceeding environmental concentrations, the persistence in the aquatic environment and bioaccumulation by biota, suggest a potential concern for aquatic biota due to their presence in the aquatic environment.

The toxicological pathways of synthetic musks, in terms for instance of detoxification, are poorly understood in mammalians and barely documented in aquatic organisms. Only a species-specific metabolization has been suggested for aquatic biota [4].

In this view, studies focusing on toxicological mechanisms of action of both compounds in fish species are needed, with particular regard to the interaction with major detoxification systems, such as cytochrome P450 responsible for 
metabolism/detoxification of both endogenous and exogenous compounds. CYP1A in particular is a major enzyme subfamily involved in phase I of the detoxification response to various xenobiotics, well characterised in fish species [13].

The involvement of CYP450 in musks metabolism is supposed to be responsible for the species-specific accumulation of these compounds. In mammalian species, MX affects various CYPs, such as CYP1A1, CYP1A2, CYP2B and CYP3A. Rats exposed to high doses of MX $(0.1 \mathrm{mM})$ show strong induction of CYP1A2, presumably by post-transcriptional induction [14]. Other studies in mice and rats showed that MX (up to $200 \mathrm{mg} / \mathrm{kg} / \mathrm{day}$ ) caused phenobarbital-like pretranslational induction of CYP2B mRNA and protein levels. Significant inhibition of the related pentoxyresorufin-O-deethylase (PROD) activity, probably related to MX amino metabolites, and no effects on CYP1A1 have also been reported $[15,16]$. Long-term exposure of adult Long Evans rats to low doses of MX (0.7-0.8 mg/kg/day) showed increased CYP1A and CYP2B proteins and related resorufin activities [17], similar to those observed at higher doses of acute exposure. On the contrary AHTN resulted to be hepatotoxic, without altering CYPs activities [18].

The only study on fish indicated that among musks, MX was the strongest inhibitor of CYP1A activity in vitro $\left(\mathrm{IC}_{50} 37 \pm 7 \mu \mathrm{M}\right)$ while $\mathrm{AHTN}$ determined a $30 \%$ inhibition [19]. Hence a different mechanism of interaction of $\mathrm{MX}$ and AHTN with CYP1A is likely.

The aim of the present study is to investigate the interaction of MX and AHTN with CYP1A by looking at gene transcription (cypla) and EROD activity in Poeciliopsis lucida hepatoma cell line (PLHC-1). PLHC-1 are commonly used in ecotoxicology to study toxicological pathways of chemicals, including PPCPs [20]. With regard to the biotransformation pathway, they are suitable by virtue of their high capacity to metabolize xenobiotics and they also express the gene for the aryl receptor AhR [21]. MX and AHTN were studied in short term exposure individually and combined with classical inducer of CYP1A as Benzo(a)pyrene (B(a)P) and 3,3'-4,4',5-pentachlorobiphenyl (PCB126).

\section{Materials and methods}

\subsection{Cell culture}

PLHC-1 cells (ATCC; LGC Promochem, Teddington UK) were kindly provided by Dr Tvrtko Smital of Ruder Boskovich Institute, Zagreb, Croatia. They were grown in $75 \mathrm{~cm}^{2}$ plastic flasks (PBI International) at $30^{\circ} \mathrm{C}$ in $20 \mathrm{ml}$ Dulbecco's Modified Eagles Medium (Sigma-Aldrich) supplemented with 5\% FBS (Invitrogen). Cells were subcultured every 4 days by detaching with $1 \mathrm{ml}$ per flask of 1:4 trypsin-EDTA solution (Gibco).

\subsection{Neutral red assay}

Cell viability was measured by neutral red assay [22]. Cells were grown in $200 \mu \mathrm{l} /$ well of medium for $24 \mathrm{~h}$. One hundred micro litres of medium was then 
removed and replaced with the same volume of medium containing serial dilutions (range $0-250 \mu \mathrm{M}$ ) of MX and AHTN (LGC standards) or 0.1-2 $\mu \mathrm{M}$ $\mathrm{B}(\mathrm{a}) \mathrm{P}$ and 1nM PCB 126 (Sigma-Aldrich) dissolved in DMSO (maximum concentration $0.1 \%$ ). Unexposed cells and DMSO-exposed cells were used as controls. The plates were incubated for another $24 \mathrm{~h}$. The medium was then removed and the plates washed with $200 \mu \mathrm{l}$ PBS, adding $100 \mu \mathrm{l}$ neutral red medium, containing $40 \mu \mathrm{g} / \mathrm{ml}$ Neutral Red dissolved in DMEM. Cells were incubated for $2 \mathrm{~h}$ under culture conditions. The medium was then removed and the cells washed with $150 \mu \mathrm{l}$ PBS. Then $100 \mu 1$ neutral red destain solution $(50 \%$ ethanol, $49 \%$ deionized water, $1 \%$ glacial acetic acid) was added and the plate shaken for $10 \mathrm{~min}$. The optical density (OD) of neutral red extract was measured by spectrophotometer at $540 \mathrm{~nm}$. Each experiment was performed at least three times. The IC50 for MX and AHTN were calculated by fitting the OD of a typical experiment to a classical sigmoidal dose-response model using GraphPad Prism5 software.

\subsection{RNA extraction and Q-PCR}

In order to evaluate CYP1A modulation at gene transcription by MX, AHTN, and the two known inducers $\mathrm{B}(\mathrm{a}) \mathrm{P}$ and $\mathrm{PCB} 126$, singly and combined, cells were grown in $4 \mathrm{ml} /$ well of medium for $24 \mathrm{~h}$. Two millilitres of medium was then removed and replaced with $2 \mathrm{ml}$ medium containing $\mathrm{MX}(2,4$ and $20 \mu \mathrm{M}$ final concentrations ) and AHTN (1 nM, $2 \mu \mathrm{M}$ f.c.) singularly dissolved in DMSO $0.1 \%$, B(a)P $2 \mu \mathrm{M}$ f.c. and B(a)P $2 \mu \mathrm{M}$ combined with MX $20 \mu \mathrm{M}$ and $2 \mu \mathrm{M}$ AHTN. PCB126 $1 \mathrm{nM}$ f.c. and PCB126 $1 \mathrm{nM}$ combined with $1 \mathrm{nM}$ and $2 \mu \mathrm{M}$ AHTN. The plates were incubated for another 6 and $24 \mathrm{~h}$. The medium was then discarded and the plates washed twice with $1.2 \mathrm{ml}$ PBS. Cells dissolved in PBS were recovered with a cell scraper and centrifuged 10 minutes at $1200 \mathrm{x}$ g. Cell pellets were stored at $-80^{\circ} \mathrm{C}$.

Total RNA was isolated using Qiagen RNeasy MiniKit (Qiagen) according to the manufacturer's protocol. RNA was treated with DNase from RNase-Free DNase set (Qiagen) to avoid any traces of genomic DNA. RNA concentrations were measured using a Shimadzu spectrophotometer at $260 \mathrm{nM}$. $250 \mathrm{ng}$ total RNA was transcribed to cDNA using i-script cDNA Reverse Transcription Kit (Biorad). Real-time PCR was used to evaluate cypla gene expression. Specific primers were designed using IDTDNA www.idtdna.com. 18S rRNA was used as housekeeping gene based on high stability in this cell line. Primer sequences for PLHC-1 r $18 S$ were kindly provided by Jovica Loncar from Ruder Boskovic Institute, Zagreb, Croatia.

The following primers were used:

cypla Fw: 5'-GCATTTGGCGTGCTCGAAGAAA-3',

Rev: 5'-TTGCAGATGTGCTCCTCCAACA-3';

rl8S Fw: 5'-CCTTTAACGAGGATCCATTGGA-3',

Rev: 5'-CGAGCTTTTTAACTGCAGCAACT-3'.

Each amplification reaction contained $12.5 \mu \mathrm{l}$ SYBR green mix, $1 \mu \mathrm{l}$ cDNA and $0.75 \mu \mathrm{l}$ forward and reverse primers $10 \mu \mathrm{M}$, in $25 \mu \mathrm{l}$ total volume. The 
cycling parameters were: 3 min denaturing at $95^{\circ} \mathrm{C}, 40$ cycles at $95^{\circ} \mathrm{C}$ for $15 \mathrm{~s}$, annealing at $55^{\circ} \mathrm{C}$ for $45 \mathrm{~s}$, elongation at $72^{\circ} \mathrm{C}$ for $1 \mathrm{~min}$. All primer pairs gave a single peak of dissociation in all reactions, and no amplification occurred in reactions without template. PCR efficiencies for each primer were determined from a standard curve using dilutions of pooled cDNA $\left(\mathrm{r}^{2}>0.97\right.$ for all primers). Data was analysed by the $\Delta \Delta \mathrm{Ct}$ method [23].

\subsection{EROD activity}

EROD activity was determined by microplate assay [24]. Cells were grown in $200 \mu \mathrm{l} /$ well of medium for $24 \mathrm{~h}$. One hundred micro litres of medium was then removed and replaced with $100 \mu \mathrm{l}$ of medium containing serial dilutions $(0-20$ $\mu \mathrm{M})$ of MX, AHTN, B(a)P and PCB 126 and in combination, dissolved in DMSO (maximum concentration 0.1\%). Unexposed cells and DMSO-exposed cells were used as controls. The plates were incubated for another 6 or $24 \mathrm{~h}$ and then washed with $200 \mu \mathrm{l}$ PBS, adding $100 \mu \mathrm{l} 2 \mu \mathrm{M}$ 7-ethoxyresorufin (7-ER) dissolved in phosphate buffer $\mathrm{pH} 8.0$ to each well. The kinetics of resorufin production were monitored for $10 \mathrm{~min}$ using a Victor3 microplate reader (Wallak) at $\lambda_{\text {Excitation }}=530 \mathrm{~nm}$ and $\lambda_{\text {Emission }}=590 \mathrm{~nm}$. Protein content was quantified by a photometric assay [25] using bovine serum albumin as standard $\left(0-0.5 \mathrm{mg} / \mathrm{L} \mathrm{r}^{2}=0.9728\right)$. Results of EROD assay shown in Tables 1 and 2 are expressed as mean $\pm \mathrm{SD}$ of at least three independent experiments.

\section{Results}

\subsection{Citotoxicity}

After $24 \mathrm{~h}$ of exposure, a different cytotoxicity has been observed for the two compounds with an $\mathrm{LC}_{50}$ of $35.76 \mu \mathrm{M}$ for AHTN and $\mathrm{LC}_{50} 123.6 \mu \mathrm{M}$ for MX. No cytotoxic effect was encountered at the concentration of $2 \mu \mathrm{M}$ of B(a)P and 1nM PCB126 (data not shown).

\subsection{Interaction with CYP1A}

After $6 \mathrm{~h}$ of exposure to MX, a dose-dependent reduction in cypla gene transcription was observed with respect to control. At $24 \mathrm{~h}$, the same pattern was observed but with slight induction at the lowest concentration $(2 \mu \mathrm{M})$ and still a dose-dependent reduction at the higher concentrations of $4 \mu \mathrm{M}$ and $20 \mu \mathrm{M}$ (Fig. 1). Co-exposure to $\mathrm{MX}$ with $\mathrm{B}(\mathrm{a}) \mathrm{P}$ did not alter cypla transcription levels compared to cells exposed to B(a)P alone (Fig. 1).

On the contrary after $6 \mathrm{~h}$ AHTN determined a slight induction of cypla transcription reaching maximum induction of 2.3 folds respect to controls at 2 $\mu \mathrm{M}$. No modulation of cyp 1 a transcription was observed after $24 \mathrm{~h}$ (Fig. 2). Coexposure to AHTN with PCB126 and B(a)P at 6 h determined a 55\% reduction of cypla transcription respect to the inducers alone which seemed to recover at $24 \mathrm{~h}$. No differences on cypla transcription were evident at $24 \mathrm{~h}$ between single exposure to inducers and combined to AHTN (Fig. 2). 


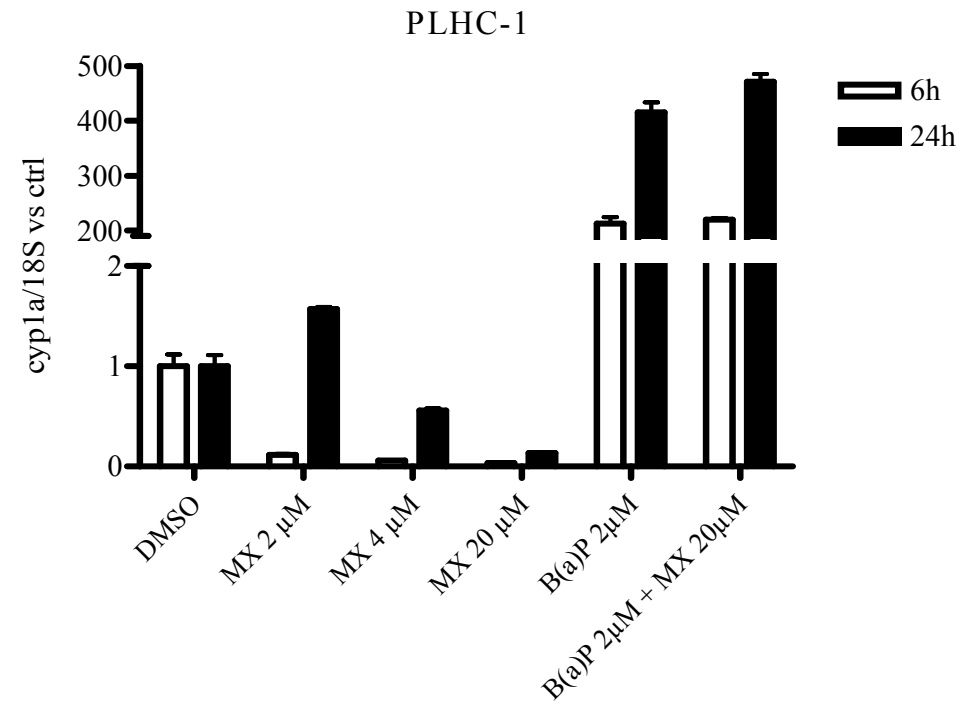

Figure 1: Transcription levels of cypla/18S of the cell line PLHC-1, exposed for 6 and $24 \mathrm{~h}$ to $\mathrm{MX}, \mathrm{B}(\mathrm{a}) \mathrm{P}$ and $\mathrm{B}(\mathrm{a}) \mathrm{P}$ plus $\mathrm{MX}$ with respect to control (DMSO). Results are mean $\pm \mathrm{SD}(\mathrm{N}=3)$.

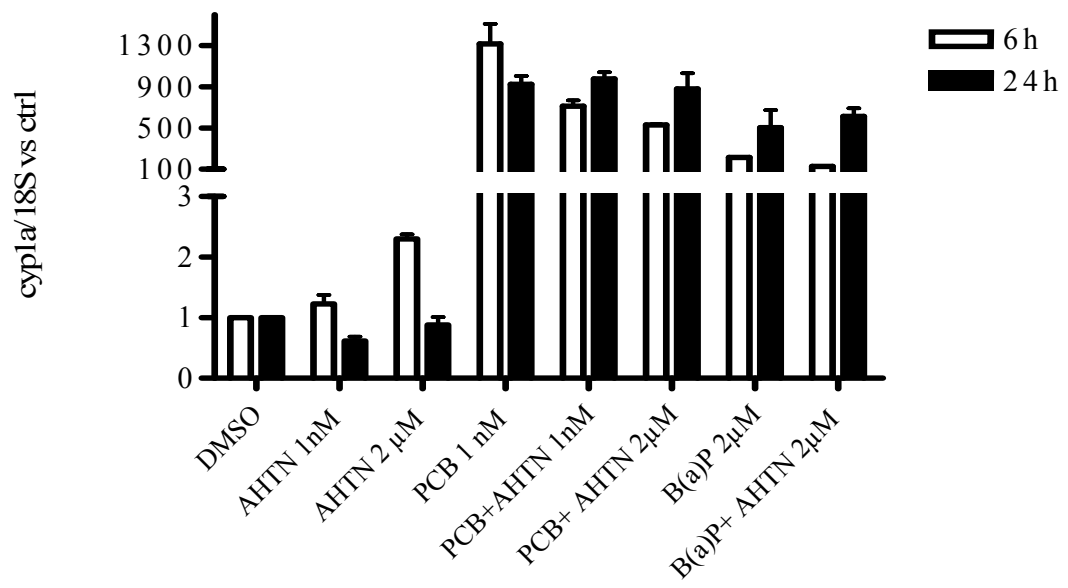

Figure 2: Transcription levels of cypla/18S of the cell line PLHC-1, exposed for 6 and $24 \mathrm{~h}$ to AHTN, B(a)P and PCB126 singly and combined with respect to control (DMSO). Results are mean $\pm \mathrm{SD}(\mathrm{N}=3)$.

PLHC-1 cells exposed to MX for $6 \mathrm{~h}$ all showed increasing EROD activity, with maximum induction at the highest concentration of MX $(20 \mu M)$. On the 
contrary, at 24 h, MX caused a dose-dependent decrease. Only a slight increase (about 2 folds vs ctrl) of EROD activity was detectable at $6 \mathrm{~h}$ and $24 \mathrm{~h}$ of exposure to AHTN (Tab. 1). Co-exposure with both MX and AHTN did not alter EROD activity induced by PCB126 and B(a)P (Tab. 2).

Table 1: $\quad$ Modulation of EROD activity by tested compounds at $6 \mathrm{~h}$ and $24 \mathrm{~h}$. Indicated are maximal fold increase in activity \pm s.d. and the maximal concentration where the highest activity has been found.

\begin{tabular}{ccccc}
\hline & 6h & \multicolumn{3}{c}{$\mathbf{2 4 h}$} \\
\hline & Max folds induction & conc Max & Max folds induction & conc Max \\
\hline MX 6h & $5.5 \pm 0.53$ & $20 \mu \mathrm{M}$ & $0.24 \pm 0.1$ & $20 \mu \mathrm{M}$ \\
AHTN & $2.32 \pm 0.79$ & $2 \mu \mathrm{M}$ & $2.18 \pm 0.01$ & $4 \mu \mathrm{M}$ \\
B(a)P & $80.35 \pm 37.75$ & $0.2 \mu \mathrm{M}$ & $79.15 \pm 1.10$ & $0.2 \mu \mathrm{M}$ \\
PCB & $40.53 \pm 3.55$ & $1 \mathrm{nM}$ & $149.79 \pm 16.34$ & $1 \mathrm{nM}$ \\
\hline
\end{tabular}

Table 2: Induction of EROD activity by tested compounds in co-exposure at $24 \mathrm{~h}$. Indicated are fold increase in activity \pm s.d.

\begin{tabular}{cc}
\hline & EROD induction vs ctrl \\
\hline PCB126 1 nM + AHTN $2 \mu \mathrm{M}$ & $160.83 \pm 8.87$ \\
B(a)P 0.2 $\mu \mathrm{M}+$ AHTN $2 \mu \mathrm{M}$ & $67.11 \pm 5.31$ \\
PCB126 1 nM + MX 2 $\mu \mathrm{M}$ & $127.43 \pm 2.96$ \\
B(a)P 0.2 $\mu \mathrm{M}+$ MX 2 $\mu \mathrm{M}$ & $88.85 \pm 10.07$ \\
\hline
\end{tabular}

\section{Discussion}

The different extent of MX and AHTN citotoxicity observed in the present study has been already reported in liver rainbow trout cell lines (RTL-W1), in which a 30 folds lower $\mathrm{LC}_{50}$ was measured for AHTN respect to MX [26]. These findings underline the need for more caution in the use of AHTN in household and personal care products. In Europe the use of AHTN is higher than nitromusk as MX with 358 tonnes per year for AHTN against 67 for MX (OSPAR data for 2000) [27].

Concerning CYP1A, results suggest that the MX and AHTN act differently in the PLHC-1 model.

MX seemed to affect CYP1A at transcriptional and enzymatic level with different profiles of cypla transcription after $6 \mathrm{~h}$ and $24 \mathrm{~h}$ of exposure. At $6 \mathrm{~h}$, MX significantly reduced basal levels of transcription of the cypla gene in a dose-dependent manner. Partial recovery of the reduction but not dose-dependent occurred within $24 \mathrm{~h}$. Positive feed-back involving amino metabolites, which act in the opposite manner to the parent compound, seems likely and reflects observations in mammals in vivo [15]. Although the cellular transformation pathways of MX are unknown, after 6 and $24 \mathrm{~h}$ of exposure our results suggest 
that MX and its metabolites undergo different CYP1A biotransformation. Regarding the co-exposure experiment, MX reduced also cypla basal transcription but did not alter cypla induction by B(a)P. Other authors reported similar behaviour of rainbow trout hepatocyte cultures exposed in vitro to $17 \beta-$ estradiol (E2) and 17 $\alpha$-ethinylestradiol (EE2), respectively [28,29]. In both studies, E2 and EE2 inhibited basal expression of the cypla gene and no interaction with induced levels of cypla by $\beta \mathrm{NF}$ (co-exposure) was observed. The effects on cypla expression found in the present study indicate that more research is needed into the behaviour of MX and its metabolites towards ER.

In mammals, it has been postulated that the MX cellular pathway is not mediated by AhR. A peculiar profile of drug-metabolizing enzyme induction by MX, not mediated by AhR, was suggested [14]. According to these authors, MX determined specific induction of CYP1A2 and phase II enzymes by a posttranscriptional induction mechanism. This hypothesis is in line with previous observations [30]. Under co-exposure conditions with 2-aminoanthracene (2$\mathrm{AA})$ or aflatoxin $\mathrm{B}_{1}\left(\mathrm{AFB}_{1}\right)$, MX caused an increase in genotoxicity of these compounds, whereas co-exposure with $\mathrm{B}(\mathrm{a}) \mathrm{P}$ did not cause any increase in toxicity. Thus the present results sustain the hypothesis of a distinct signalling pathway for MX not mediated by AhR.

On the contrary AHTN did not alter significantly cypla basal levels but decreased cypla induction by $\mathrm{B}(\mathrm{a}) \mathrm{P}$ and PCB126. A potential role of AHTN as competitive antagonist of AhR could thus be hypothesized. AHTN seems to interact with CYP1A similarly to other pollutants as PBDE (85) and PCB (105, 128) $[31,32]$.

The involvement of metabolites which act in the opposite manner to the parent compound, seems likely for both musks, due to the different profile of cypla transcription.

With regard to the effects of MX on EROD activity, a reduction was generally observed after 6 and $24 \mathrm{~h}$ of exposure, as observed for gene transcription, except for the increase at the highest concentrations $(10-20 \mu \mathrm{M})$. A similar inhibitory effect was reported in the microsomal fraction of carp in vitro, where MX reduced EROD activity by $71 \pm 5 \%$ [19]. Besides clear evidence of inhibition of EROD activity by MX in vitro, the present results show temporal permanence of the inhibitory effect over $24 \mathrm{~h}$. The large discrepancy between 6 and $24 \mathrm{~h}$ exposure to the higher concentrations suggests compensatory positive feedback in the first $6 \mathrm{~h}$ of exposure, seemingly cancelled out over $24 \mathrm{~h}$. A possible explanation could be the observed significant reduction in cypla transcription.

With regard to AHTN, no interaction with EROD activity is observed both at $6 \mathrm{~h}$ and at $24 \mathrm{~h}$, both in single and in co-exposure. Consequently, the alteration at the transcriptional level by AHTN does not seem to interfere with the catalytic function of CYP1A.

This observation is in agreement with what has been reported in carp [19], where a higher ability of nitromusk to interact with CYP1A compared to polycyclic musk has been observed. AHTN in fact determines only a slight inhibition of EROD activity compared to other musks while it has been reported 
as the strongest inhibitor of CYP3A activity (BFCOD) [19]. Moreover in rat microsomes AHTN seems not altering EROD activity [18], thus confirming the hypothesis that it is not metabolized by CYP1A, but possibly by other enzymes as CYP3A.

Based on the overall results, it can be hypothesized that other enzymes could be responsible for rapid metabolism of MX and AHTN in PLHC-1.

First useful data have been thus obtained from the present study in order to understand toxicological pathways of MX and AHTN in relation to the CYP1A system in fish. Overall results of this study suggest a different mechanism of interaction with CYP1A of a nitro musk as MX and a polycyclic musk as AHTN. Therefore, both compounds seem to affect CYP1A detoxification of toxic compounds known inducers of the system as PAHs and PCBs. A reduction in the detoxification of toxic molecules could affect negatively fish cells with unexpected detrimental effects for aquatic organisms and the ecosystem.

\section{Conclusions}

The present study clarifies the interaction of MX and AHTN with the CYP1A system in fish both in single and co-exposure with classical CYP1A inducers.

Regarding MX, data suggests that it interferes with the biotransformation system but not involving AhR mediated pathway as confirmed by co-exposure with B(a)P. AHTN seems not to be metabolized by CYP1A but at the same time able to reduce the metabolization of classical toxic inducers as $\mathrm{B}(\mathrm{a}) \mathrm{P}$ and the dioxin-like PCB 126. Exposure to musks could thus result in reduced detoxification capacity of CYP1A and may also interfere with important physiological processes in the organism. Therefore, under conditions of chronic exposure unexpected adverse effects could occur, especially in areas chemically impacted by mixture of toxic pollutants. The use of co-exposure experiments confirmed a great investigative tool to clarify the interaction and behaviour of emerging contaminants in respect of important cellular defence systems.

\section{Acknowledgements}

The study was financed by the Italian Ministry for Universities and Research (MIUR) based on PRIN project 2007J23NNX_001 2007.

The authors are grateful to Roko Zaja and Jovica Loncar from the Ruder Boskovic Institute for setting up the PLHC-1 analysis and to Tvrtko Smital for great advice and support.

\section{References}

[1] Daughton, C.G., \& Ternes T.A., Pharmaceuticals and personal care products in the environment: agent of subtle change? Environmental Health Perspectives, 107, pp. 907-938, 1999. 
[2] Rimkus, G., Polycyclic fragrances in the aquatic environment. Toxicology Letters, 111, pp. 37-56, 1999.

[3] Gaterman, R., Hühnerfuss, H., Rimkus, G., Attar, A., \& Kettrup A., Occurrence of musk xylene and musk ketone metabolites in the aquatic environment. Chemosphere, 36, pp. 2535-2547, 1998.

[4] Gaterman R., Biselli S., Hühnerfuss H., Rimkus G., Hecker M., Karbe L., 2002. Synthetic musks in the environment. Part 1: Species dependent bioaccumulation of polycyclic and nitro musk fragrances in freshwater fish and mussels. Archives of Environmental Contamination and Toxicology, 42, pp. 437-446, 2002.

[5] Sumner, N.R., Guitart, C., Fuentes, G., \& Readman, J.W., Inputs and distributions of synthetic musk fragrances in an estuarine and coastal environment; a case study. Environmental Pollution, 158, pp. 215-22, 2010.

[6] Rudel, H., Bohmer W., \& Schroter-Kermani, C., Retrospective monitoring of synthetic musk compounds in aquatic biota from German rivers and coastal area. Journal of Environmental Monitoring, 8, pp. 812-823, 2006.

[7] Luckenbach, T., Corsi, I., \& Epel, D., Fatal attraction: synthetic musk fragrances compromise multixenobiotic defense systems in mussels. Marine Environmental Research 58, pp. 215-9 2004.

[8] Luckenbach, T., \& Epel, D., Nitromusk and polycyclic musk compounds as long-term inhibitors of cellular xenobiotic defence systems mediated through multidrug transporters. Environmental Health Perspectives 113, pp. $17-24,2005$.

[9] Carlsson, G., \& Norrgren L., Synthetic musk toxicity to early life stages of zebrafish (Danio rerio). Archives of Environmental Contamination and Toxicology, 46, pp. 102-105, 2004.

[10] Chou, Y., \& Dietrich, D.R., Interactions of nitromusk parent compounds and their amino-metabolites with the estrogen receptors of rainbow trout (Oncorhynchus mykiss) and the South African clawed frog (Xenopus laevis). Toxicology Letters, 111, pp. 27-36, 1999.

[11] Schreurs, R.H.M.M., Legler, J., Artola-Garicano, E., Sinnige, T.L., Lanser, H., \& Van Der Burg B., In vitro and in vivo antiestrogenic effects of polycyclic musks in zebrafish. Environmental Science and Technology 38, pp. 997-1002, 2004.

[12] Yamauchi, R., Ishibashi, H., Hirano, M., Mori, T., Kim, J-W., \& Arizono, K., Effects of synthetic polycyclic musks on estrogen receptor, vitellogenin, pregnane $\mathrm{X}$ receptor, and cytochrome $\mathrm{P} 450$ 3A gene expression in the livers of male medaka (Oryzias latipes). Aquatic Toxicology 90, pp. 261268, 2008.

[13] Goksøyr, A., \& Förlin, L., The cytochrome P-450 system in fish, aquatic toxicology and environmental monitoring. Aquatic Toxicology 22, pp. $287-$ $312,1992$.

[14] Iwata, N., Minegishi, K., Suzuki, K., Ohno, Y., Igarashi, T., Satoh, T., \& Takahashi, A., An unusual profile of musk xylene-induced drugmetabolizing enzymes in rat liver. Biochemical Pharmacology, 45, pp. 1659-1665, 1993. 
[15] Lehman-McKeeman, L.D., Caudill, D., Vassallo, J.D., Pearce, R.E., Madan, A., \& Parkinson, A., Effects of musk xylene and musk ketone on rat hepatic cytochrome P450 enzymes. Toxicology Letters, 111, pp. 105115, 1999.

[16] Lehman-McKeeman, L.D., Johnson, D.R., \& Caudill, D., Induction and inhibition of mouse cytochrome P-450 2B enzymes by musk-xylene. Toxicology and Applied Pharmacology, 142, pp. 169-177, 1997.

[17] Suter-Eichenberger, R., Boelsterli, U.A., Conscience-Egli, M., Lichtensteiger, W., \& Schlumpf, M., CYP 450 enzyme induction by chronic oral musk xylene in adult and developing rats. Toxicology Letters, 115, pp.73-87, 2000.

[18] Steinberg, P., Fischer, T., Arand, M., Park, E., Elmadfa, I., Rimkus, G., Brunn, H., Dienes, \& H-P., Acute hepatotoxicity of the polycyclic musk 7-acetyl-1,1,3,4,4,6-hexamethyl-1,2,3,4-tetrahydronaphthaline (AHTN). Toxicology Letters, 111, pp. 151-160, 1999.

[19] Schnell, S., Martin-Skilton, R., Fernandes, D., \& Porte, C., The interference of nitro- and polycyclic musks with endogenous and xenobiotic metabolizing enzymes in carp: an in vitro study. Environmental Science and Technology, 43, pp. 9458 - 9464, 2009.

[20] Fent, K., Fish cell lines as versatile tools in ecotoxicology: assessment of cytotoxicity, cytochrome P4501A induction potential and estrogenic activity of chemicals and environmental samples. Toxicology in Vitro, 15, pp. $477-488,2001$.

[21] Hahn, M.E., The aryl hydrocarbon receptor. A comparative perspective. Comparative Biochemistry and Physiology C. 121, pp. 23 - 54, 1998.

[22] Repetto, G., del Peso, A., \& Zurita, J.L., Neutral red uptake assay for the estimation of cell viability/cytotoxicity. Nature Protocols 3, pp. 1125-1132, 2008.

[23] Pfaffl, M., A new mathematical model for relative quantification in realtime RT-PCR. Nucleic Acid Research, 29, pp. 2002-2007, 2001.

[24] Traven, L., Žaja, R., Lončar, J., Smital, T., \& Mićović, V., CYP1A induction potential and the concentration of priority pollutants in marine sediment samples - In vitro evaluation using the PLHC-1 fish hepatoma cell line. Toxicology in Vitro, 22, pp. 1648 - 1656, 2008.

[25] Bradford, M., A rapid and sensitive method for the quantitation of microgram quantities of protein utilizing the principle of protein-dye binding. Analytical Biochemistry 72, pp. 248-254, 1976.

[26] Schnell, S., Bols, N.C., Barata, C., \& Porte, C., Single and combined toxicity of pharmaceuticals and personal care products (PPCPs) on the rainbow trout liver cell line RTL-W1. Aquatic Toxicology, 93, pp. 244-252, 2009.

[27] OSPAR Commission. Ospar Background Document on Musk Xylene and Other Musks, Hazardous Substances Series; OSPAR Commission: London, pp. 45, 2004. 
194 Environmental Health and Biomedicine

[28] Navas, J.M., \& Segner, H., Estrogen-mediated suppression of cytochrome P4501A (CYP1A) expression in rainbow trout hepatocytes: role of estrogen receptor. Chemico - Biological Interactions, 138, pp. 285-298, 2001.

[29] Grans, J., Wassmur, B., \& Celander, M.C., One-way cross-talk between arylhydrocarbon receptor $(\mathrm{AhR})$ and estrogen receptor (ER) signalling in primary cultures of rainbow trout hepatocytes. Aquatic Toxicology, 100, pp. 263-270, 2010.

[30] Mersch-Sundermann, V., Emig, M., \& Reinhardt, A., Nitro musks are cogenotoxicants by inducing toxifying enzymes in the rat. Mutation Research, 356, pp. 237-245, 1996.

[31] Chen, G., Konstantinov, A.D., Joyce, E.M., Bols, N.C., and Bunce, N.J., Synthesis of polybrominated diphenyl ethers and their capacity to induce CYP1A by the Ah receptor mediated pathway. Environmental Science and Technology, 35, pp. 3749-3756, 2001.

[32] Hestermann, E.V., Stegeman, J.J., \& Hahn, M.E., Relative contributions of affinity and intrinsic efficacy to aryl hidrocarbon receptor ligand potency. Toxicology and Applied Pharmacology, 168, pp. 160-172, 2000. 